\title{
THE ACTION OF SERICIN PROTEIN ON INITIAL NERVE REPAIR, ASSOCIATED OR NOT WITH SWIMMING IN WISTAR RATS
}

\author{
AÇÃO DA PROTEÍNA SERICINA NO REPARO NERVOSO INICIAL, ASSOCIADA OU NÃO À \\ NATAÇÃO, EM RATOS WISTAR
}

\author{
ACCIÓN DE LA PROTEÍNA SERICINA EN LA REPARACIÓN NERVIOSA INICIAL, ASOCIADA O \\ NO A LA NATACIÓN, EN RATONES WISTAR
}

\author{
Jean Carlos Debastiani, ${ }^{1}$ André Junior Santana, ${ }^{1}$ Alana ludemila de Frettas Tavares, ${ }^{1}$ Juliana Roncini Gomes da Costa, ${ }^{1}$ Luiz Gustavo Vasconcelos Machado, ${ }^{1}$ \\ Regina Inês Kunz, ${ }^{1}$ Lucinéa de Fátima Chasko Ribeiro, ${ }^{1}$ Rose Meire Costa, ${ }^{1}$ Gladson Ricardo Flor Bertolinl ${ }^{1}$ \\ 1. Universidade Estadual do Oeste do Paraná (Unioeste), Lesion Studies and Physical Therapy Resources Laboratory and Functional and Structural Biology Laboratory, Cascavel, PR, Brazil.
}

\begin{abstract}
Objective: To analyze the effects of sericin treatment, associated or not with swimming with load exercise, on initial sciatic nerve repair after compression in Wistar rats. Methods: Forty animals were divided into five groups: control, injury, injury-sericin, injury-swimming and injury-sericin-swimming. During the axonotmesis procedure, the sericin was applied to the injury-sericin and injury-sericin-swimming groups. The injury-swimming and injury-sericin-swimming groups performed the swimming with load exercise for five days, beginning on the third postoperative day (PO), and were evaluated for function, nociception and allodynia. Euthanasia was performed on the 8th PO day and fragments of the nerve were collected and prepared for quantitative and descriptive analysis in relation to the total amount of viable nerve fibers and non-viable nerve fibers, nerve fiber diameter, axon diameter and myelin sheath thickness. Results: There was no significant improvement in the sciatic functional index up to the eighth day. The Von Frey test of the surgical scar and plantar fascia indicated a reduction in pain and allodynia for the injury-swimming and injury-sericin-swimming groups. The morphological analysis presented similar characteristics in the injury-sericin, injury-swimming and injury-sericin-swimming groups, but there was a significant difference in the number of smaller non-viable nerve fibers in the injury-swimming and injury-sericin-swimming groups as compared to the others. Conclusions: Isolated sericin protein presented proinflammatory characteristics. There was improvement of allodynia and a decrease in the pain at the site of the surgical incision, possibly linked to an aquatic effect. There was no acceleration of nerve repair on the eighth day after the injury. Level of Evidence I; High quality randomized clinical trial with or without statistically significant difference, but with narrow confidence intervals.
\end{abstract}

Keywords: Biocompatible materials; Nerve crush; Swimming; Silk.

\section{RESUMO}

Objetivo: Analisar os efeitos do tratamento da sericina, associada ou não ao exercício de natação com sobrecarga, sobre o reparo inicial do nervo isquiático após compressão em ratos Wistar. Métodos: Foram separados 40 animais em cinco grupos, sendo eles: controle; lesão; lesão-sericina; lesão-natação e lesão-sericina-natação. Durante o procedimento de axonotmese, a sericina foi aplicada sobre a lesão nos grupos lesão-sericina e lesão-sericina-natação. Os grupos lesão-natação e lesão-sericina-natação realizaram o exercício de natação com sobrecarga durante cinco dias, iniciando no terceiro dia pós-operatório (PO), sendo avaliados quanto à função, nocicepção e alodinia. A eutanásia foi realizada no oitavo dia $P O$, sendo que dois fragmentos do nervo foram coletados e preparados para análise quantitativa e descritiva em relação a quantidade total de fibras nervosas viáveis, não viáveis, diâmetro da fibra nervosa, do axônio e espessura da bainha de mielina. Resultados: No índice funcional isquiático não houve melhora significativa até o oitavo dia. O teste de Von Frey na cicatriz cirúrgica e fáscia plantar indicaram redução do quadro álgico e alodinia para os grupos lesão-natação e lesão-sericina-natação. A análise morfológica apresentou características semelhantes nos grupos lesão-sericina, lesão-natação e lesão-sericina-natação, porém houve diferença significativa das fibras nervosas não viáveis menores nos grupos lesão-natação e lesão-sericina-natação em relação aos demais. Conclusões: A proteína sericina isolada apresentou características pró-inflamatórias. Houve melhora da alodinia e diminuição do quadro álgico no local da incisão cirúrgica relacionadas a possível efeito aquático. Não houve aceleração do reparo nervoso no oitavo dia após a lesão. Nível de Evidência l; Estudo clínico randomizado de alta qualidade com ou sem diferença estatisticamente significante, mas com intervalos de confiança estreitos.

Descritores: Materiais biocompatíveis; Compressão nervosa; Natação; Seda.

\section{RESUMEN}

Objetivo: Analizar los efectos del tratamiento de la sericina, asociada o no al ejercicio de natación con sobrecarga, sobre la reparación inicial del nervio isquiático después de compresión, en ratones Wistar. Métodos: Se separaron 40 animales en cinco grupos, siendo: control; lesión; lesión-sericina; lesión-natación y lesión-sericina-natación. Durante el procedimiento de axonotmesis, la sericina fue aplicada sobre la lesión en los grupos lesión-sericina y lesión-sericina-natación. Los grupos lesión-natación y lesión-sericina-natación realizaron el ejercicio de natación con sobrecarga durante cinco días, iniciándose en el tercer día postoperatorio (PO), siendo evaluados cuanto a la función,

Study conducted at the Universidade Estadual do Oeste do Paraná (Unioeste), Cascavel, PR, Brazil.

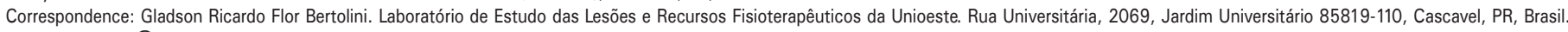
gladsonricardo@gmail.com 
nocicepción y alodinia. La eutanasia fue realizada en el octavo día $P O$, siendo que dos fragmentos del nervio fueron recolectados y preparados para análisis cuantitativo y descriptivo, con relación a la cantidad total de fibras nerviosas viables, no viables, diámetro de la fibra nerviosa, del axón y espesor de la vaina de mielina. Resultados: En el índice funcional isquiático no hubo mejoría significativa hasta el octavo día. La prueba de "Von Frey" en la cicatriz quirúrgica y la fascia plantar indicaron reducción del cuadro álgico y alodinia, para los grupos lesiónnatación y lesión-sericina-natación. El análisis morfológico presentó características similares en los grupos lesión-sericina, lesión-natación y lesión-sericina-natación, pero hubo diferencia significativa de las fibras nerviosas no viables menores en los grupos lesión-natación y lesión-sericina-natación con relación a los demás. Conclusiones: La proteína sericina aislada presentó características proinflamatorias. Hubo mejora de la alodinia y disminución del cuadro álgico en el lugar de la incisión quirúrgica, relacionadas al posible efecto acuático. No hubo aceleración de la reparación nerviosa en el octavo día después de la lesión. Nivel de Evidencia I; Ensayo clínico aleatorizado de alta calidad con o sin diferencia estadísticamente significativa, pero con intervalos de confianza estrechos.

Descriptores: Materiales biocompatibles; Compresión nerviosa; Natación; Seda.

\section{INTRODUCTION}

Peripheral nerve lesions (PNLs) are frequent, especially traumatic ones, such as those from compression, crushing and stretching that result in changes in voluntary motor function leading to morbidity and disability in activities of daily life and work. Treatment is generally long with consequent increased costs for the public health care and social security systems. ${ }^{1}$ They have a higher incidence in young adults. ${ }^{2}$

Several therapeutic approaches are used in the treatment of PNLs ${ }^{3}$ and the benefits of physical exercise in the peripheral nerve regeneration include increased strength, endurance and mobility, ${ }^{4,5}$ in addition to improved myelination and development of nerve fibers. ${ }^{6}$

Among the exercises, those in the aquatic environment have a good prognosis, revealing functional improvement following sciatic nerve injury, ${ }^{5,6}$ favoring the removal of degenerated myelin ${ }^{7}$ and the recovery of axonal diameter, ${ }^{8}$ in addition to stimulating the growth and development of new cells and increasing the presence of neuronal growth factors. ${ }^{9}$ Teodori et al. ${ }^{5}$ reported that swimming applied in acute and late phase nerve compression models revealed an acceleration in the sciatic nerve regeneration process.

However, other studies have demonstrated delays in functional recovery from this type of exercise ${ }^{8}$ or no effect on muscle strength, ${ }^{10}$ and because of the slow regeneration process, problems such as inadequate nerve reinsertion and nerve function inefficiency are possible, impacting directly the final result. ${ }^{1}$ This denotes the need for research about the effect of physical exercise on nerve repair and its association with auxiliary procedural substances.

In this sense, silk sericin biopolymer has a potential biomedical application. This protein, produced by the silkworm caterpillar (Bombyx mori), together with fibroin, make up the silk cocoon. ${ }^{11}$ Sericin has been shown to have an influence on the regeneration of cartilaginous tissue, favoring cell proliferation, ${ }^{12}$ accelerating cutaneous tissue regeration, ${ }^{13}$ acting on the healing process and possibly leading to lower levels of inflammatory mediators. ${ }^{14,15}$ Wang et al. ${ }^{16}$ demonstrated its neuroprotector effect in neuronal repair, promoting the growth of neurons in vitro. In addition, other potential effects have made sericin the focus of interest by several segments, given its possible uses.

Thus, sericin presents broad application possibilities, such as PNL repair, and thus, the objective of this study was to analyze the effects of sericin treatment, associated or not with exercises involving swimming with load, on sciatic nerve repair during the initial nerve repair period following compression in Wistar rats.

\section{METHODS}

\section{Sample characterization}

This study followed all experimental procedures and was approved by the Animal Ethics Committee. The sample population comprised forty Wistar rats, aged $8 \pm 2$ weeks and weighing between 200 and 300 grams, maintained in a controlled environment with a 12-hour light-dark cycle, room temperature of $25 \pm 1^{\circ} \mathrm{C}$, and water and feed ad libitum. These animals were equitably and randomly divided into 5 groups: control (CON), no type of procedure conducted; lesion (LES), sciatic nerve lesion protocol conducted and no treatment received; lesion-sericin (LSER), sciatic nerve lesion protocol conducted and treated with sericin; lesion-swimming (LNAT), sciatic nerve lesion protocol conducted and treatment with swimming; and lesion-sericin-swimming (LSRNT), submitted to nerve lesion, treatment with sericin and subsequently with swimming.

All animals underwent the same evaluation during the experimental period.

\section{Sciatic nerve lesion and sericin protein application}

Prior to the surgical procedure, the animals were weighed and anesthetized intraperitoneally with ketamine hydrochloride $(95 \mathrm{mg} / \mathrm{Kg})$ and xylazine hydrochloride $(12 \mathrm{mg} / \mathrm{Kg})$. Then, the animal was positioned in the prone position with abduction of the four limbs and the surgical region of the right pelvic limb was prepared. The incision was made parallel to the fibers of the femoral biceps, allowing exposure of the sciatic nerve. Axonotmesis was performed with the help of hemostatic forceps, in which the sciatic nerve was compressed for 30 seconds, using the second tooth of the serrated jaw as the pressure reference. ${ }^{17}$ The nerve compression was performed by the same researcher in all the animals. Epineural suture was then performed in the injured region with nylon 10.0 thread, to make the exact location of the lesion and collection of the nerve segments possible at the time of euthanasia. ${ }^{3}$

Afterwards, each of the LSER and LSRNT animals received a single application of $100 \mu \mathrm{L}$ of hydrolyzed sericin, ${ }^{18}$ followed by surgical closure by layer and the relocation of the nerve to preoperative conditions.

The sericin was obtained directly from $B$. mori cocoons, supplied by BRATAC Silk do Brasil (Londrina, Paraná, Brazil). The cocoons were cut into fragments of approximately $1 \mathrm{~cm}^{2}$ and submitted to a high-pressure, high-temperature extraction process in an autoclave (CS 30 - Prismatec, Itu, SP, Brazil) at $120^{\circ} \mathrm{C}$ and a pressure of $1 \mathrm{kgf} / \mathrm{cm}^{2}$ for 1 hour. ${ }^{19}$ No chemical products were added during extraction and $100 \mathrm{~mL}$ of distilled water was used for each $6 \mathrm{~g}$ of cocoon. The fibroin was separated using an 18 mesh strainer and the sericin solution was frozen $\left(-20^{\circ} \mathrm{C}\right)$ and used in hydrolyzed form during the experiment.

\section{Swimming}

The swimming experiment was conducted with a load equal to $10 \%$ of the animal body weight for 15 minutes. The load was made up of lead weights, attached to the abdominal region with a Velcro belt, aiming to prevent interference with mobility during the exercise. The protocol began on the $3^{\text {rd }}$ day following axonotmesis and was maintained until the $7^{\text {th }}$ day. The animals were euthanized on the 8th day. The load was determined daily by previous weighing of the animals.

For the ten days preceding the surgical procedure, all animals were acclimated to the swimming protocol and to the tests. The CON, LES, and LSER animals did not perform the exercise protocol, but were submitted to the aquatic environment for 10 seconds on the same days established for LNAT and LSRNT training, simulating the stress of the aquatic environment. ${ }^{20}$ An oval tank, $60 \mathrm{~cm}$ deep and with a capacity of $200 \mathrm{~L}$ was used at a temperature of $32 \pm 1^{\circ} \mathrm{C}$. 


\section{Sciatic functional index (SFI)}

To measure the sciatic functional index, we used a treadmill linked to an imaging system (Insight $\left.{ }^{\circledR}\right)$, which obtained animal footprint data. Measurements of paw length (longitudinal distance between the two extreme points of the footprint), total spread of toes (transversal distance between the two most extreme points of the footprint), total spread of the two intermediate toes, both on the experimental side and on the contralateral side, were input to a specific formula and output as negative percentages, with 0 (zero) representing normal function and -100 (negative 100) representing total loss of function. ${ }^{21}$

Five evaluations were performed. The first (EV1) was performed 24 hours before the surgical procedure, the second (EV2) on the 3rd postoperative day prior to initiating the swimming protocol, the third (EV3) also on the 3rd day but after the termination of swimming, the fourth (EV4) was conducted on the 7th day following the swimming treatment, and the fifth (EV5) was performed prior to euthanasia on the 8th postoperative day. The test sequence was established and followed during the entire experiment, the first being the SFI test, followed by the test with the Von Frey digital analgesiometer, but the order in which they were conducted was randomized in order to dilute the influence of time and fatigue in the evaluators.

\section{Digital Von Frey filament type test}

The digital Von Frey filament analgesiometer (Insight $\left.{ }^{\circledR}\right)$ consisted of the application of a filament in the region of the surgical procedure, with the animal restrained, positioned with the propylene tip positioned perpendicularly to the area, with a gradual increase in pressure exerted until the animal performed the withdrawal movement of the pelvic limb. Then the same stimulus was performed on the plantar surface of the right pelvic limb, with the animal in an elevated box with a mesh floor, making access, perpendicular positioning and gradual increase in the pressure of the filament possible, and the test was interrupted as soon as the animal raised the limb and the amount of force necessary for withdrawal was recorded. Three measurements per evaluation were performed in each region and the mean value was adopted for statistical analysis. ${ }^{22}$

\section{Collection and euthanasia}

On the 8th day after the nerve lesion procedure, the animals were weighed and anesthetized. The right sciatic nerve was collected and sectioned distally into two fragments of $1 \mathrm{~cm}$ each. The first (proximal fragment) was obtained immediately after the point of the lesion, identified by the nylon 10.0 thread, and the second (distal fragment) was collected in sequence. Following the procedure, the animals, still under the effect of the anesthetic, were euthanized.

\section{Morphological analysis}

The fragments of the sciatic nerve were fixed in buffered paraformaldehyde for 24 hours and the distal fragment was pre-stained with osmium tetroxide $2 \%$. Subsequently, they were processed for histological paraffin blocking and cut transversely at a thickness of $5 \mu \mathrm{m}$. The slides obtained from the proximal fragment were stained with hematoxylin and eosin $(H / E)^{23}$ for the descriptive analyses of the nerve, while the distal fragment was submitted to morphometric analyses. Then, the slides were photomicrographed using an Olympus BX 50 microscope.

For the morphometric analyses, the Image-Pro-Plus 6.0 program was used, in which the following parameters were observed: total quantity of viable nerve fibers (VNF), total quantity of non-viable nerve fibers (NVNF), diameter of the axon (DAX), diameter of the nerve fiber (DNF), and thickness of the myelin sheath (TMS), NVNFs being considered those without defined contours that could be measured. The nerve fibers were analyzed in terms of diameter less than or greater than $4 \mu \mathrm{m}$. This was based on the studies by Mazzer et al. ${ }^{24}$ and Mandelbaum-Livnat et al., ${ }^{25}$ which described the presence of nerve fibers with smaller and larger diameters in the sciatic nerve injuries. Four images were taken of each cut at $\times 1000$ magnification: the upper left, upper right, lower left and lower right sections. The analysis was blind in relation to the experiment groups and included 25 fibers greater and 25 fibers less than $4 \mu \mathrm{m}$ in diameter per quadrant, totaling 200 fibers per nerve or even all of them.

\section{Statistical analysis}

The results were expressed by descriptive statistics and analyzed for normality using the Shapiro-Wilk test. Once data normality was verified, analysis was conducted by one-way ANOVA with LSD post hoc test (t-test) with a significance level of 0.05, using the Bioestat 5.0 program.

\section{RESULTS}

\section{Sciatic Functional Index}

There were no significant differences between the five evaluations conducted in the CON group $(p=0.870)$. LES, LSER, LNAT and LSRNT presented identical behavior, with a significant difference between EV1, conducted before the lesion, and the other evaluations (EV2, EV3, EV4, EV5) conducted following the lesion $(p<0.001)$

In the comparison of groups by time of evaluation, there was no significant difference in EV1 among the groups $(p=0.274)$. At moments EV2, EV3, EV4 and EV5 there were differences between CON and all the other groups $(p<0.001)$ (Table 1).

\section{Digital Von Frey filament type analgesiometer test}

As regards the digital Von Frey filament type test in the region of the surgical scar, the CON showed no significant differences $(p=0.530)$. The LES and LSER behaved identically, presenting a difference from EV1 to the others $(p<0.001)$. LNAT obtained a difference from EV1 to the others $(p<0.001)$ and from EV2 to EV4 $(p=0.018)$ and to EV5 $(p=0.023)$, while LSRNT had identical behavior with a difference from EV2 to EV4 $(p=0.006)$ and to EV5 $(p=0.002)$, indicating a reduction in pain over time.

Also in terms of the surgical scar, in the comparison between groups, there was no significant difference in EV1 between the groups $(p=0.383)$. At moments EV2 and EV3, differences were observed between CON and all the other groups $(p<0.001)$. At EV4 there was a difference between CON and the others $(p<0.001)$ and from LSER to LES $(p=0.015)$ and to LSRNT $(p=0.011)$. At EV5 a difference was identified between CON and the others $(p<0.001)$, from LSER to LES $(p=0.020)$ and to LSRNT $(p<0.001)$, and from LNAT to LSRNT ( $p=0.030$ ) (Table 2).

In the plantar fascia region, CON showed no difference between the evaluations $(p=0.77)$. LES and LSER presented similarities, showing a difference between EV1 and the others $(p<0.001)$. In LNAT there was a difference between EV1 and the others $(p<0.001)$ and from EV2 to EV4 $(p=0.015)$ and to EV5 $(p<0.001)$, and from EV3 to EV5 $(p=0.004)$, while LSRNT presented a difference between EV1 and the others $(p<0.001)$ and from EV2 to EV4 $(p=0.001)$.

In the comparison of the plantar fascia between the groups, there was no difference at the moment of EV1 $(p=0.1014)$. At EV2, EV3 and EV4 differences between CON and the other groups were observed $(p<0.001)$. EV5 showed a difference between CON and other groups $(p<0.001)$ and from LNAT to LSER $(p=<0.0241)$ and to LSRNT $(p=0.0181)$ (Table 2).

Table 1. Mean and standard deviation of the SFI corresponding to euthanasia on the eighth day and statistically significant differences.

\begin{tabular}{c|c|c|c|c|c}
\hline & CON & LES & LSER & LNAT & LSRNT \\
\hline EV1 & $-12.1 \pm 24.0^{\mathrm{aA}}$ & $3.07 \pm 21.4^{\mathrm{aA}}$ & $-17.2 \pm 16.2^{\mathrm{aA}}$ & $-7.0 \pm 7.1^{\mathrm{aA}}$ & $-13.5 \pm 19.8^{\mathrm{aA}}$ \\
\hline EV2 & $-10.1 \pm 14.9^{\mathrm{bA}}$ & $-60.02 \pm 19.2^{\mathrm{bB}}$ & $-66.0 \pm 9.5^{\mathrm{bB}}$ & $-67.5 \pm 7.6^{\mathrm{bB}}$ & $-63.7 \pm 16.7^{\mathrm{bB}}$ \\
\hline EV3 & $-5.1 \pm 25.3^{\mathrm{bA}}$ & $-62.64 \pm 10.8^{\mathrm{bB}}$ & $-67.2 \pm 11.8^{\mathrm{bB}}$ & $-50.6 \pm 34.3^{\mathrm{bB}}$ & $-71.6 \pm 19.5^{\mathrm{bB}}$ \\
\hline EV4 & $-0.7 \pm 11.6^{\mathrm{bA}}$ & $-55.40 \pm 12.5^{\mathrm{bB}}$ & $-61.6 \pm 16.9^{\mathrm{bB}}$ & $-61.5 \pm 19.0^{\mathrm{bB}}$ & $-58.9 \pm 36.3^{\mathrm{bB}}$ \\
\hline EV5 & $-9.3 \pm 27.8^{\mathrm{bA}}$ & $-57.58 \pm 22.8^{\mathrm{bB}}$ & $-68.2 \pm 8.0^{\mathrm{bB}}$ & $-62.3 \pm 19.3^{\mathrm{bB}}$ & $-64.0 \pm 15.6^{\mathrm{bB}}$ \\
\hline
\end{tabular}

Note: Different lowercase letters indicate a statistically significant difference in the group when compared to its evaluations (column); different uppercase letters indicate a statistically significant difference between the groups at the time of evaluation (row). 
Table 2. Mean and standard deviation of the Von Frey tests of the surgical scar and the plantar fascia corresponding to euthanasia on the eighth day and statistically significant differences.

\begin{tabular}{|c|c|c|c|c|c|c|}
\hline & & CON & LES & LSER & LNAT & LSRNT \\
\hline \multirow{5}{*}{ Surgical Scar } & EV1 & $145.4 \pm 10.1^{\mathrm{aA}}$ & $137.2 \pm 13.6^{\mathrm{aA}}$ & $136.3 \pm 13.5^{\mathrm{aA}}$ & $130.1 \pm 10.9^{\mathrm{aA}}$ & $139.6 \pm 19.7^{\mathrm{aA}^{\mathrm{A}}}$ \\
\hline & EV2 & $143.4 \pm 13.2^{\mathrm{aA}}$ & $48.4 \pm 8.6^{\mathrm{bB}}$ & $38.1 \pm 15.5^{\mathrm{bB}}$ & $39.9 \pm 9.5^{\mathrm{bB}}$ & $38.9 \pm 14.0^{\mathrm{bB}}$ \\
\hline & EV3 & $144.7 \pm 15.9^{\mathrm{aA}}$ & $49.0 \pm 12.2^{\mathrm{bB}}$ & $36.6 \pm 15.0^{\mathrm{bB}}$ & $48.3 \pm 4.7^{\mathrm{bcB}}$ & $48.8 \pm 9.5^{\mathrm{bcB}}$ \\
\hline & EV4 & $150.0 \pm 13.5^{\mathrm{aA}}$ & $57.7 \pm 6.9^{\mathrm{bB}}$ & $44.2 \pm 11.6^{\mathrm{bC}}$ & $51.0 \pm 8.1^{\mathrm{cBC}}$ & $58.4 \pm 6.6^{\mathrm{cB}}$ \\
\hline & EV5 & $153.8 \pm 10.3^{\mathrm{aA}}$ & $54.5 \pm 9.3^{\mathrm{bB}}$ & $43.7 \pm 7.4^{\mathrm{bc}}$ & $50.5 \pm 6.9^{\mathrm{cBC}}$ & $60.6 \pm 6.8^{\mathrm{cD}}$ \\
\hline \multirow{4}{*}{ Plantar Fascia } & EV1 & $68.1 \pm 11.5^{\mathrm{aA}}$ & $68.4 \pm 13.0^{\mathrm{aA}}$ & $55.3 \pm 13.1^{1 \mathrm{~A}}$ & $68.0 \pm 10.0^{\mathrm{aA}}$ & $70.9 \pm 7.1^{\mathrm{aA}}$ \\
\hline & EV3 & $68.3 \pm 10.8^{\mathrm{aA}}$ & $35.1 \pm 11.3^{\mathrm{bB}}$ & $29.4 \pm 11.4^{\mathrm{bB}}$ & $30.5 \pm 5.3^{\mathrm{bcB}}$ & $31.4 \pm 8.9^{\mathrm{bcB}}$ \\
\hline & EV4 & $74.1 \pm 15.2^{\mathrm{aA}}$ & $39.5 \pm 7.6^{\mathrm{bB}}$ & $32.5 \pm 8.8^{\mathrm{bB}}$ & $36.0 \pm 5.6^{\mathrm{cdB}}$ & $36.7 \pm 8.2^{\mathrm{cB}}$ \\
\hline & EV5 & $69.7 \pm 11.9^{\mathrm{aA}}$ & $39.0 \pm 11.0^{\mathrm{bBC}}$ & $31.0 \pm 6.8^{\mathrm{bB}}$ & $41.6 \pm 3.6^{\mathrm{dC}}$ & $30.5 \pm 4.4^{\mathrm{bcB}}$ \\
\hline
\end{tabular}

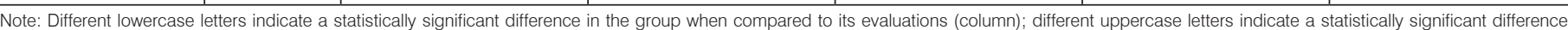
between the groups at the time of evaluation (row)

\section{Morphological analysis}

The sciatic nerve of the CON revealed normal tissue and cell characteristics, formed by nerve fibers of different diameters, myelinic and amyelinic, with the presence of Schwann fibers (Figures $1 \mathrm{~A}$ and $\mathrm{A} 1$ ). The connective tissue that forms the endoneurium, perineurium and epineurium, also had normal characteristics. In the LES group, most of the nerve fibers were altered with diameters and forms different from the CON group, an increased number of Schwann cells, inflammatory infiltrate, forming clusters of giant cells and microphages (Figures 1B and B1).

In the LSER, LNAT and LSRNT groups (Figures 1C-1E and C1$\mathrm{E} 1)$, the morphological aspects were similar to each other, with axonal alteration, hypercellularity due to the increase in the number of Schwann cells and the presence of inflammatory infiltrate.

In all groups, the count of the total number of VNFs, for fibers with diameters greater than and for fibers with diameter less than $4 \mu \mathrm{m}$, showed a statistical difference in relation to CON $(p<0.001)$. The greater than $4 \mu \mathrm{m}$ NVNFs showed a difference between CON and the other groups $(p<0.010)$, while for the less than $4 \mu \mathrm{m} N V N F$ variable differences were observed between $\mathrm{CON}$ and the other groups $(p<0.001)$, between LES and all the groups (LSER $p=0.028$, LNAT $p<0.001$ and LSRNT $p<0.001)$, and between LSER and all the groups (LNAT $p=0.038$ and LSRNT $p=0.006$ ).

In the analysis of the mean DNF of the greater than $4 \mu \mathrm{m}$ groups, we only observed differences between CON and the other groups $(p<0.001)$. There was no difference between the mean DNF of the smaller than $4 \mu \mathrm{m}$ groups $(p=0.860)$. The same was true for the evaluation of the mean DAX of the larger $(p=0.200)$ and smaller $(p=0.630)$ fibers. In the evaluation of TMS in the larger fiber group, there was a difference from CON to all the others $(p<0.001)$, with no difference being observed in the smaller fibers $(p=0.086)$ (Table 3$)$.

\section{DISCUSSION}

The peripheral location of the sciatic nerve exposes it to nerve injuries, especially those that produce sciatica as a symptom, which interferes with the transmission of nerve impulses and can cause functional disability, with potential negative socioeconomic impact affecting mainly young and productive individuals. ${ }^{2,26}$

The injury model used in this study was proposed by Bridge et al., ${ }^{18}$ producing a compression in which rupture of axons occurs and triggers a process of Wallerian degeneration distal to the injury, which occurred in all the groups submitted to injury in this study. This process affects the structure of the nerve fibers within a period of around two to three days, with a cascade of events kicked off from the site of the injury that involves, among other factors, the migration of macrophages, the proliferation of Schwann cells, changes in the constituents of the extracellular matrix and reorganization of the endoneural space, as observed in this study, in addition to the production of cytokines and an increase in neutrophins. ${ }^{26}$
The hypercellularity observed in the injured groups results from several cell types aimed at tissue and functional reorganization; such as macrophages, present in the distal stump, which remove the degenerating myelinic remains between the second and seventh days after the injury. With the initial extrusion of the myelin sheath, up to three days following axonal injury, the division and proliferation of Schwann cells begins, which explains the large quantity of cells observed on the eighth day following the injury. Schwann cells also perform phagocytosis and are associated with the production of chemotactic substances that align along the basal lamina, forming Büngner bands and assist in guiding axonal growth. ${ }^{26}$

Peripheral axonal regeneration depends on a rapid and efficient inflammatory response, as Schwann cells and macrophages communicate through cytokine networks, controlling phagocytosis and growth factors. In rodents, the release of proinflammatory cytokines begins from three to five hours after the injury and the number of macrophages, both endogenous and systemic, reaches its maximum from four to seven days after injury, this explaining the hypercellularity observed on the eighth day after the injury. It is of note that delays in this process can lead to a loss of regenerative capacity. ${ }^{26}$

We found no similar studies on the use of sericin in PNLs for the purpose of comparison, these being the first morphological and functional data resulting from the application of this biomaterial either directly or not on the injury. However, the perspective regarding the application of sericin in other tissues was promising, ${ }^{12-16}$ raising expectations for its action in peripheral nerve repair.

As regards the SFI results, there was a difference only between the $\mathrm{CON}$ and the other groups in the comparison between groups and, individually, there was only a difference from EV1, performed prior to the injury. Thus, the injury model was effective in causing significant changes in the motor function of the animals and continued in all the intervention groups up until the eighth day after the nerve injury.

Oliveira et al. ${ }^{8}$ reported that swimming with load in the initial phase of nerve regeneration impaired functional recovery and its association with electrical stimulation had no effect on nerve repair, proposing that intervention protocols should avoid load. However, Lós et al. ${ }^{27}$ stated that early intervention in the aquatic environment following surgical repair of a complete peripheral nerve injury does not compromise the regenerative process and stimulates physiological revascularization. Similarly, Teodori et al. ${ }^{5}$ reported that swimming exercise in the acute and late phases of peripheral sciatic nerve injury by crushing in Wistar rats accelerates nerve regeneration and improves synaptic transmission. However, the data obtained in this study did not reveal functional improvement in the injured groups on the eighth day following the injury.

In terms of changes in pain related to interventions, as evidenced by means of digital analgesiometer testing performed in the region of the surgical incision, we found that, in the comparison by group, CON did not show any alterations, whereas in the other groups EV1 was different from the subsequent evaluations, since EV1 was prior 

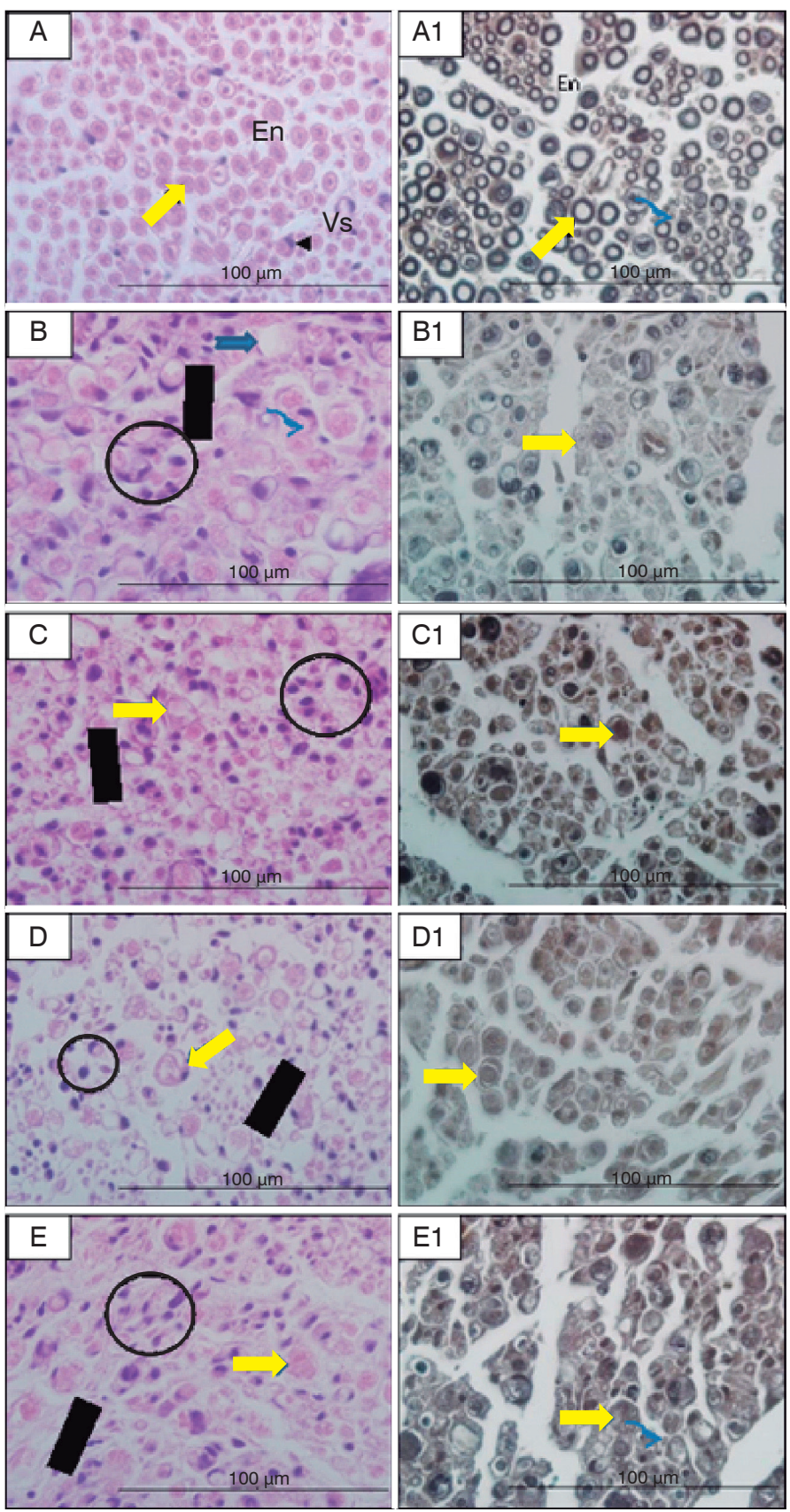

Figure 1. Photomicrographs of the sciatic nerve of Wistar rats on the 8th day after injury, transverse section, hematoxylin-eosin (A - E) and osmium tetroxide (A1 - E1). A and A1, control group, nerve fibers intact, with axon and myelin sheath (thin arrow), Schwann cell nucleus (tip of arrow), blood vessel (Vs) and endoneurium (En). B and B1, lesion group with degenerated nerve fibers (blue arrow), inflammatory infiltrate (dotted circle) and Schwann cells. $\mathrm{C}$ and $\mathrm{C} 1$, sericin group; D and D1, swimming group; and $\mathrm{E}$ and $\mathrm{E} 1$, sericin and swimming group with degenerated nerve fibers, Schwann cell nucleus, hypercellularity, inflammatory infiltrate, small-diameter fibers (curved arrow) and blood vessels.

to the surgical procedure, but in the LNAT and LSRNT groups there was an increase in the nociceptive threshold over time, related to an effect of the aquatic exercise, since only the groups with intervention by exercise showed this behavior. This supports studies that cite exercise as an effective strategy to control the inflammatory and pain processes because it alters the levels of inflammatory cytokines, neurotrophins, neurotransmitters and endogenous opiods. ${ }^{28}$

In EV2 and EV3, there was a difference between CON and the other groups, and in AV4, we observed a difference from LSER to
LES and LSRNT, with LSER having the worst performance, indicating that sericin, when used alone and administered in the initial repair phase, showed proinflammatory action. Bhattacharjee et al. ${ }^{29}$ state that the use of sericin increase the inflammatory response by causing hypersensitivity, resulting from exacerbated immune responses. However, Svennigsen and Dahlin ${ }^{26}$ claim that the increase in inflammatory response is an important aspect to be considered in nerve regeneration. Aramwit et al. ${ }^{14}$ pointed out that sericin is not toxic and can promote healing of skin wounds, as the levels of inflammatory mediators IL-1 1 and TNF- $\square$ observed seven days following injury are significantly less than in wounds treated without sericin. In a comparative study of silk fibers with and without sericin, it was observed that in fibers with sericin there was activation of inflammatory cells, such as polymorphonucleated cells, leukocytes, eosinophils and macrophages. ${ }^{30}$

The test performed in the plantar fascia region with the digital analgesiometer sought to identify changes by allodynia, with reference to the sciatic nerve pathway. In the individual comparison, LER and LSER behaved identically. In LNAT there was a difference from EV2 to EV4 and EV5, and in LSRNT from AV2 to AV4, showing an improvement in sensitivity in both groups. This can be associated with treatment in the aquatic environment, given that only the groups that underwent treatment with swimming exercise showed improvement over time. This result corroborates the studies by Kami, Tajima and Senba, ${ }^{28}$ in which they suggest that swimming exercise as a factor to improve allodynia in neuropathic pain models, but the mechanisms are not fully understood.

At moment EV5, the LNAT was different from LSER and LSRNT, having better performance, but was not different from LES, which had the worst values associated with the use of sericin, once again showing a proinflammatory effect.

Regarding the morphometric findings, we observed that the quantity of VNFs, both those greater than and less than $4 \mu \mathrm{m}$, showed a difference between CON and all the other groups, proving that up until the eighth day, the nerve injury was still significant. The group of NVNFs less than $4 \mu \mathrm{m}$ showed a difference between LES and all the others and also between LSER and all the others, but with the lowest values observed, while LNAT and LSRNT were different from all the groups, obtaining the highest values. It is not possible to say whether these NVNFs are in the process of regeneration or degradation. The tendency is for larger altered fibers to be in the process of degeneration and smaller fibers to be in regeneration. Thus, the regeneration process, still in its initial phase, showed no signs of viability, justifying the lack of adequate functionality observed, but the numerical difference between the groups, which was significantly greater in LNAT and LSRNT, may indicate that the proinflammatory action of the protein sericin was regulated by the swimming exercise.

There was a difference between $\mathrm{CON}$ and the other groups in the DNF greater than $4 \mu \mathrm{m}$, but not between the DNF less than 4 $\mu \mathrm{m}$, nor was there a significant difference in either the DAX greater than $4 \mu \mathrm{m}$ or less than $4 \mu \mathrm{m}$. The TMS of fibers greater than 4 $\mu \mathrm{m}$ showed a difference in CON, while in the smaller fibers there was no difference, revealing little influence in these variables on the eighth day.

Considering that the inflammatory process is fundamental to nerve regeneration, ${ }^{26}$ studies have shown that sericin induces proinflammatory cytokines and increases phagocytosis, in addition to stimulating transcription factor NF-Kb and p38 kinase, which are deeply involved in the regulation of proinflammatory pathways. ${ }^{29}$ Teodori et al. ${ }^{5}$ reported that the exercise of swimming performed in the acute phase after sciatic nerve injury by crushing in Wistar rats accelerates nerve regeneration and improves synaptic transmission. Thus, based on the results of our study, it seems that swimming exercise regulates the proinflammatory action of sericin protein. However, studies with longer treatment times are necessary to analyze the behavior of this relationship in a later phase of nerve repair. 
Table 3. Comparisons of the mean values of viable nerve fibers (VNF), non-viable nerve fibers (NVNF), diameter of nerve fibers (DNF), diameter of axons (DAX) and thickness of the myelin sheath (TMS) on the eighth postoperative day, grouped by fiber diameter greater than and less than $4 \mu \mathrm{m}$.

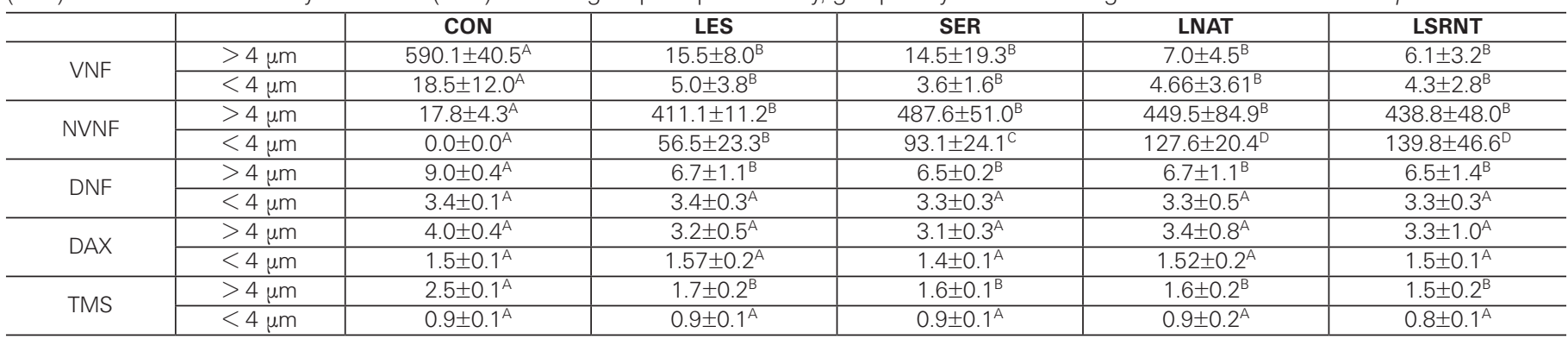

Note. Different letters indicate statistically significant difference between the groups (row).

\section{CONCLUSION}

Sericin protein applied directly to the sciatic nerve injury elicited proinflammatory characteristics that appear to be modulated when associated with swimming exercise. Isolated swimming showed an improvement in hyper-nociception as compared to the other interventions, linked to a possible aquatic effect. There were no significant morphological signs of acceleration of the nerve repair process on the eighth day following injury in any of the treatments.

All authors declare no potential conflict of interest related to this article.

CONTRIBUTION OF THE AUTHORS: Each author made significant individual contributions to this manuscript. JCD (0000-0001-8845-6333)* writing, review, execution of nerve lesion surgeries, conducting of treatments, production and analysis of the histological slides; AJS (0000-0003-1282-0746)*: review of the final text, execution of nerve injury surgeries, conducting of treatments, assistance with the production and analysis of histological slides; ALFT (0000-0002-8687-1231): review of the final text, execution of nerve injury surgeries, conducting of treatments, assistance with the production and analysis of histological slides; JRGC (0000-0001-5145-5935)*: review of the final text, execution of nerve injury surgeries, conducting of treatments, assistance with the production and analysis of histological slides; LGVM (0000-0002-1786-5073)*: review of the final text, execution of nerve injury surgeries, conducting of treatments, assistance with the production and analysis of histological slides; RIK (0000-0003-1510-7022*: review of the final text, assistance with the production and analysis of histological slides; LFCR (0000-0001-5174-7399)*: review of the final text, assistance with the production and analysis of histological slides; RMC (0000-0002-5344-5076)*: review of the final text, assistance with the production and analysis of histological slides; GRFB (00000003-0565-2019)*: revision of the final text, assistance with the surgeries, writing of the text, conducting of the statistical analysis, intellectual concept, and the preparation of the entire research project. *ORCID (Open Researcher and Contributor ID).

\section{REFERENCES}

1. Brull R, Hadzic A, Reina MA, Barrington MJ. Pathophysiology and etiology of nerve injury following peripheral nerve blockade. Reg Anesth Pain Med. 2015:40(5):479-90.

2. Miranda GE, Torres RY. Epidemiology of traumatic peripheral nerve injuries evaluated with electrodiagnostic studies in a tertiary care hospital clinic. P R Health Sci J. $2016 ; 35(2): 76-80$.

3. Savastano LE, Laurito SR, Fitt MR, Rasmussen JA, Polo VG, Patterson SI. Sciatic nerve injury: A simple and subtle model for investigating many aspects of nervous system damage and recovery. J Neurosci Methods. 2014;227:166-80.

4. Nijs J, Kosek E, Oosterwijck JV, Meeus M. Dysfunctional endogenous analgesia during exercise in patients with chronic pain: to exercise or not to exercise? Pain Physician. 2012;15(3 Suppl):ES205-13.

5. Teodori RM, Betini J, Oliveira LS, Sobral LL, Takeda SYM, Montebelo MIL. Swimming exercise in the acute or late phase after sciatic nerve crush accelerates nerve regeneration Neural Plast. 2011; 2011(1):1-8.

6. Jang S, Lee J. Effects of physical exercise on the functional recovery of rat hindlimbs with impairments of the sciatic nerve as assessed by $2 \mathrm{D}$ video analysis. $\mathrm{J}$ Phys The Sci. $2015 ; 27(3): 935-8$.

7. Sarikcioglu $\mathrm{L}$, Oguz $N$. Exercise training and axonal regeneration after sciatic nerve injury. Intern J Neurosci. 2001:109(3-4):173-1.

8. Oliveira LS, Sobral LL, Takeda SYM, Betini J, Guirro RRJ, Somazz MC, et al. Estimulación eléctrica y natación en la fase aguda de la axonotmesis: influencia sobre la regeneración nerviosa y la recuperación funcional. Rev Neurol. 2008:47(1):11-5.

9. Dishman RK, Berthoud H, Booth FW, Cotman CW, Edgerton VR, Fleshner MR, et al. Neurobiology of exercise. Obesity (Silver Spring). 2006;14(3):345-56

10. Coradini JG, Kakihata CMM, Kunz RI, Errero TK, Bonfleur ML, Bertolini GRF. Avaliação da força de preensão em ratos Wistar, normais e obesos, submetidos à natação com sobrecarga após compressão do nervo mediano. Rev Bras Reumatol. 2015;5(1):43-7.

11. Barajas-Gamboa JA, Serpa-Guerra AM, Restrepro-Osorio A, Álvarez-López C. Sericin applications: a globular silk protein. Ing Compet. 2016;18(2):193-206.

12. Dinescu S, Galateanu B, Albu M, Lungu A, Radu E, Hermenean A, et al. Biocompatibility assessment of novel collagen-sericin scaffolds improved with hyaluronic acid and chondroitin sulfate for cartilage regeneration. Biomed Res Int. 2013;2013:598056

13. Ersel M, Uyanikgil Y, Akarca FK, Ozcete E, Altunci YA, Karabey F, et al. Effects of silk sericin on incision wound healing in a dorsal skin flap wound healing rat model. Med Sci Monit. 2016;22(1):1064-78.

14. Aramwit P, Kanokpanont S, De-Eknamkul W, Srichana T. Monitoring of inflammatory mediators induced by silk sericin. J Biosci Bioeng. 2009;107(5):556-61

15. Padol AR, Jayakumar K, Mohan K, Manochaya S. Natural biomaterial silk and silk proteins: Applications in tissue repair. International Journal of Materials and Biomaterials Applications. 2012;2(4):19-24

16. Wang Z, Wang J, Yang J, Luo Z, Yang W, Xie H, et al. A neuroprotective sericin hy- drogel as an effective neuronal cell carrier for the repair of ischemic stroke. ACS Appl Mater Interfaces. 2015;7(44):1-34

17. Bridge PM, Ball DJ, Mackinnon SE, Nakao Y, Brandt K, Hunter DA, et al. Nerve crush injuries - A model for axonotmesis. Exp Neurol. 1994;127(2):284-90

18. Dias FJ, Issa JPM, Coutinho-Netto J, Fazan VPS, Sousa LG, Iyomasa MM, et al. Morphometric and high resolution scanning electron microscopy analysis of low-level laser therapy and latex protein (Hevea brasiliensis) administration following a crush injury of the sciatic nerve in rats. J Neurol Sci. 2015:349(1-2):129-37.

19. Gimenes ML, Silva VR, Vieira MGA, Silva MGC, Scheer AP. High molecular sericin from Bombyx mori coccons: Extraction and recovering by ultrafiltration. International journal of Chemical Engineering and Applications. 2014:5(3):226-71.

20. Peretti AL, Rosa CT, Errero TK, Baretta V, Schneider SCS, Bertolini GRF. Avaliação comportamental de ratos treinados em natação forçada. Scientia Medica. 2015;25(1):1-13

21. Monte-Raso W, Barbieri CH, Mazzer N, Fazan VPS. Os efeitos do ultra-som terapêutico nas lesões por esmagamento do nervo ciático de ratos: análise funcional da marcha. Rev Bras Fisioter. 2006:10(1):113-9.

22. Vivancos GG, Verri Jr WA, Cunha TM, Schivo IRS, Parada CA, Cunha FQ, et al. An electronic pressure-meter nociception paw test for rats. Braz J of Med Biol Res. 2004;37(1):391-9.

23. Junqueira LC, Junqueira LMMS. Técnicas básicas de citologia e histologia.1th ed. São Paulo: Santos;1983.

24. Mazzer PYCN, Barbieri CH, Mazzer N, Fazan VPS. Avaliação qualitativa e quantitativa das lesões agudas por esmagamento do nervo isquiático do rato. Acta Ortop Bras. 2006;14(6):220-5

25. Mandelbaum-Livnat MM, Almog M, Nissan M, Loeb E, Shapira Y, Rochkind S. Photobiomodulation triple treatment in peripheral nerve injury: nerve and Muscle Response. Photomed Laser Surg. 2016;34(12):638-45.

26. Svennigsen AF, Dahlin LB. Repair of the peripheral nerve - Remyelination that Works. Brain Sci. 2013:3(3):1182-97.

27. Lós DB, Silva IB, Lira KDS, Andrade RF, Moraes SRA. Efeito da natação na regeneração do nervo ciático após neurotmese experimental. Rev Fisioter S Fun. 2016;5(1):23-9.

28. Kami K, Tajima F, Senba E. Exercise-induced hypoalgesia: potential mechanisms in animal models of neuropathic pain. Anat Sci Int. 2017;92(1):79-90.

29. Bhattacharjee M, Schultz-Thater E, Trella E, Miot S, Das S, Loparic M, et al. The role of 3D structure and protein conformation on the innate and adaptive immune responses to silkbased biomaterials. Biomaterials. 2013;34(33):8161-71.

30. Liu H, Ge Z, Wang Y, Toh SL, Sutthikhum V, Goh JC. Modification of sericin-free silk fibers for ligament tissue engineering application. J Biomed Mater Res B Appl Biomater. 2007:82(1):129-38. 